\title{
Modelling the Process to Access the Spanish Public University System Based on Structural Equation Models
}

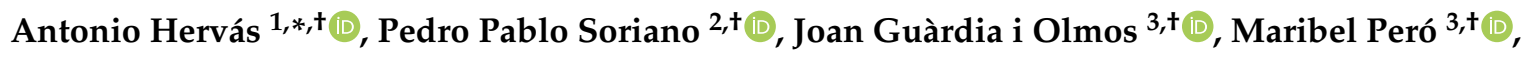 \\ Roberto Capilla ${ }^{4,+}+(\mathbb{1})$ and José Miguel Montañana ${ }^{5,+(-)}$ \\ 1 Instituto Matemática Multidisciplinar, Universitat Politècnica de València, Camí de Vera, s/n, \\ 46022 València, Spain \\ 2 SEPyC, Universitat Politècnica de València, Camí de Vera, s/n, 46022 València, Spain; \\ psoriano@upvnet.upv.es \\ 3 Dept. de Psicologia Social i Psicologia Quantitativa, Universitat de Barcelona, Passeig Vall d'Hebron 171, \\ 08035 Barcelona, Spain; jguardia@ub.edu (J.G.i.O.); mpero@ub.edu (M.P.) \\ 4 Dept. Ingeniería Electrónica, Universitat Politècnica de València, Camí de Vera, s/n, 46022 València, Spain; \\ rcapilla@eln.upv.es \\ 5 High Performance Computing Center Stuttgart (HLRS), University of Stuttgart, Nobelstraße 19, \\ 70569 Stuttgart, Germany; jmmontanana@gmail.com \\ * Correspondence: ahervas@mat.upv.es \\ + Authors contributed equally to this work.
}

Received: 18 March 2020; Accepted: 2 June 2020; Published: 4 June 2020

\begin{abstract}
Currently, one of the challenges of universities is attracting talent in students, researchers, and teachers. The transition from high school to college requires a student to take a succession of decisions that will shape their future. For this reason, knowledge of the motivations of the students, their family, and their personal environment, to choose a particular degree and/or university to pursue their higher studies, would allow universities to efficiently adjust their recruitment strategies. In this article, a study was developed based on a structural equation model of the access to the Spanish Public University System (SUPE), which can help with supply and demand problems, recruitment actions and policies, and other strategic decisions. This was done through an extensive survey of first-year students of Spanish universities. The results allowed us to obtain the parameters of the model, which showed that the fit between the model and the data obtained were excellent at a global level and acceptable as well in all knowledge areas. The objective of the structural model was to provide a general view of the behavior of the students when deciding the degree and university in which they are going to study, and can help in the decision making of university leaders and to understand some behaviors of the Spanish Public University System.
\end{abstract}

Keywords: higher education management; social models; graphs and networks applications; clustering; cluster analysis; complex networks

\section{Introduction}

The transition from High School to university is, for the student and in some cases for their families, one of the determining moments in their life. The conditions of access to university differ for each country, but in any case, each student must take a succession of decisions that will shape their future.

The increase in the number of universities, the competition between them and funding challenges motivates universities to offer an attractive and competitive product, to guarantee the usefulness of 
the product for the future of the student, to invest efforts and resources in student recruitment actions, to improve the institution's prestige [1], and to enhance performance indicators [2].

Spanish universities as a whole have more than 300,000 new students every year. Thus, Spanish universities dedicate significant efforts and resources to compete to attract the best students. The university managers seek to make use of the tools available in this competition process: big data, academic analytics, analytic methods, statistical techniques, and predictive models improve the decision-making procedures in recruitment, in management, and in the process of teaching [3-5].

The knowledge of the motivations of the students, their families, and their personal environment, to choose a particular degree and / or university to pursue their higher studies, would allow universities to efficiently adjust their recruitment strategies. This problem has been studied by different authors, who analyzed the personal aspects [6,7], as well as those aspects related to the procedures established in each country to access the university system, [8-10], or those procedures established by the universities themselves [11,12].

In European countries, the students have access to university after some form of entrance examination [13,14]. In other countries, there is a specific test for some degrees [15]. Particularly well-known cases are the Chinese National College Entrance Examination (NCEE), known as Gaokao [16]; the access test in South Korea, the College Scholastic Aptitude Test or CSAT [17]; and the examination access in Japan, the Daigaku nyūgaku shiken.

The requirements for public university access in the USA vary between a generalized acceptance policy, called an "open door admission policy", and the most demanding ones based on the academic results of the last 4 years of school, and an access test known as "American College Testing ACT" or "College Board's Scholastic Aptitude Test SAT" (historically, ACT has been the most popular in the central states and the SAT, in all other states) [18]. In the most competitive universities, the admission is a process based on the individual relationship of the students with each university, a process of application/acceptance/rejection, in which the policy of financial aid and grants of each institution plays a decisive role [19].

As early as 1978, Murphy and McGarrity [19] established the confidence in the institution and quality of the system as a key element in the decision of the American students. These results were consistent in the case of specific groups: engineering, [12] and recruitment of women and ethnic minorities [20-22]. Some authors focused on the access process by considering other factors, such as the academic results and the use of new technologies, [23], the socio-economic situation of the students, [24], or the retention of students to avoid the dropping out of students [25,26].

In the case of Spain, in the academic year 2015-2016, there were 82 universities, of which 50 were public universities and 32 were private. They admitted 221,767 new students, where the numbers of enrolled students were 1,286,868 undergraduates, 166,908 Master's degree students, and 49,496 students in the doctorate program. In 2015-2016, for whole of the Spanish University System, 2061 degrees, 3070 master degrees, and 999 doctorate programs were achieved in public universities; while in the private universities, 664 degrees, 741 master degrees, and 77 doctorate programs were completed [27].

In Spain, the public university system has a larger number of students than private universities. In particular, the public system collects $86.81 \%$ of the undergraduate students, $68.42 \%$ of the master's degree, and $96 \%$ of the students on a doctoral degree. The access procedure differs from the public to private universities. The access to private universities is based on an application-acceptance process, where each university establishes its own criteria.

The procedure for access to the Spanish public university system (SUPE) is regulated by law and each university offers a limited number of places for each degree, following the current legislation. Students must pass an entrance examination known as PAU (Spanish entrance examination) [28]. Currently, the examination system has been renamed as EBAU (Baccalaureate Assessment for University Access). If the students pass, then they can request admission by providing a preference ordered list. The administration (government), according to the marks obtained in the PAU and 
the academic record, will assign a seat according to their order of preference and the availability of vacancies.

For an outside observer, it might appear that in Spain, there appears to be no need for recruitment at all, because students who pass the entrance exam simply rank order their preferences for public university attendance and the available slots are filled by a simple rank ordering of applicants by preference and exam scores. This would indicate that there is a simple solution to a complex problem.

Virtually all public universities carry out actions to recruit students, either from the point of view of attracting vocations, [29,30], for restless students, [31], or gender [32]. There are even initiatives from external institutions, [33]. The services of Orientation and Information of the Universities are in charge of these tasks and work in a coordinated way [34].

Nonetheless, there are degrees with much more demand than supply, and others with more supply than demand. This relationship between supply and demand is related to the subjective perceptions that students have about the degrees $[7,35]$. These perceptions often do not conform to reality and are not based on any proven or reliable criteria $[2,6,7,10]$. Authors, such as [20] and the European Student's Union, (www.esib.org), showed the variables of the students' selection based on a non-phenomenological and non-contrasted model. For the Spanish case, authors, such as [6,7], showed the students demand as a result of a social value granted to the degree and the institution, based on more or less reliable and significant data or criteria.

In [35], Hervás et al. proposed a structural model adapted to the SUPE, in which authors assumed that the election process was affected by two large groups of factors: In the first place were social factors, related to the social perception of the degree and the university, and the employability. Secondly, individual factors related to the student and their own interests, whether academic or personal, and which were assessed by a survey proposed in [36]. The authors showed that context data should be added to these factors, unrelated to the perceptions but related to the supply of seats, the demand, and its temporal evolution. This model of structural equations takes into account the complex relationships between the different structures measured, and it has provided the first instrument for a psychometric analysis of access to the SUPE.

\section{Objectives}

Our objective will be to perform an analysis of the process of access to the SUPE from the structural model proposed in [35], using the questionnaire proposed in [36] (see Figure 1), and to determine if the motivations of the students who access a particular degree and/or university are different from those that access another.

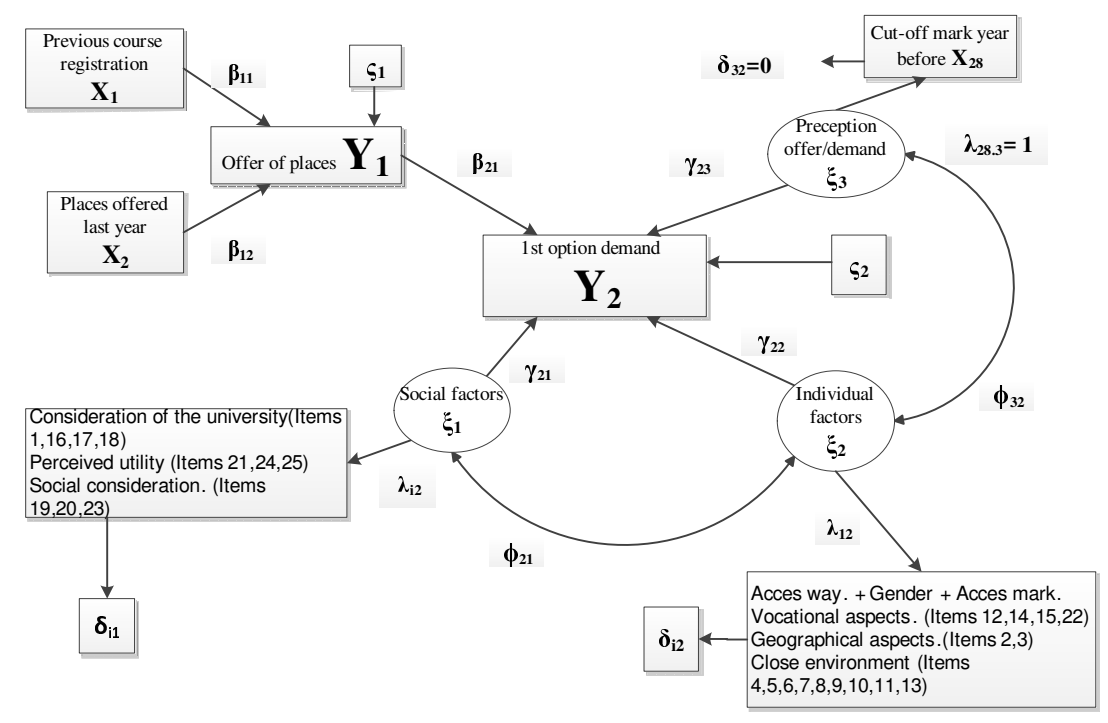

Figure 1. Diagram of the structural model. 
After this, we aim that these results will be of help in the decision-making processes related to the supply and demand problems, actions, and policies, and other strategic decisions of the university leaders.

In the general model, proposed by [35], and in the associated questionnaire, which appeared in [36], there are three types of elements:

\section{Context data}

As the work of $[35,37]$ has shown in this process, there are factors associated with the preinscription mechanism in Spain, such as the degree cut-off marks, the number of seats offered in each degree and even the gender of the students, as the selections for the first option are not independent of that variable.

2. Individual factors

- Vocational aspects.

- Influence of the surrounding environment.

- Geographic location.

3. Social factors

- University consideration.

- Perceived employability.

- Social consideration.

The structural equations that can be specified are given as:

$$
\begin{aligned}
& Y_{1}=\beta_{11} X_{1}+\beta_{12} X_{2}+\zeta_{1} \\
& Y_{2}=\beta_{21} Y_{1}+\gamma_{21} \xi_{1}+\gamma_{22} \xi_{2}+\gamma_{23} \xi_{3}+\zeta_{2} .
\end{aligned}
$$

under the restrictions:

$$
\begin{aligned}
E\left(X_{i}\right) & =E\left(Y_{i}\right)=E\left(\xi_{i}\right)=0 \\
\operatorname{Var}\left(X_{i}\right) & =\operatorname{Var}\left(Y_{i}\right)=\operatorname{Var}\left(\xi_{i}\right)=1 . \\
E\left(\epsilon_{i} \varepsilon_{j}\right) & =E\left(\delta_{i} \delta_{j}\right)=E(\eta \varepsilon)=E(\xi \delta)=E\left(\zeta_{i} \zeta_{j}\right)=0 .
\end{aligned}
$$

As all distributions have been normalized and share values of mean 0 and variance 1 , the values of the parameters $\gamma_{i j}$ indicate the variation that occurs in the endogenous variable when the exogenous variable varies in a standard deviation. The $\gamma_{i j}$ are then a measure of the sensitivity of the endogenous variable $i$ to the changes in the exogenous variable $j$.

\section{Material and Methods}

\subsection{Sample}

Since the academic year 2009-2010 to 2012-2013, several samples of diverse populations of first-year students from some universities of the SUPE were selected. This was done to cover the analysis and validation phases of the model and questionnaire used.

In the final phase, during the 2012-2013 academic year, more than 12,000 surveys were sent via e-mail and just over 3000 were sent on paper. The survey included students from 31 public universities, in an accidental non-probabilistic sampling that allowed the coverage of practically all the Spanish territory, and all types of public universities: general, technological, old, young, large, medium, and small. The questions were chosen in such a way so that their psychometric properties were not altered 
by doing it online or on paper. In particular, some collaborators preferred to do surveys on paper to guarantee that students answered them even if they did not have access to online equipment.

A total of 6405 surveys were collected, of which 4330 were sent through web questionnaires and 1475 on paper. Among all those surveys, we eliminated all those with incomplete answers or those from students who did not enroll for the first time in the degree. This reduced the number of surveys to a total of 5111 valid surveys.

The distribution by areas was as follows, 319 of Arts and Humanities, 211 of Sciences, 545 of Health Sciences, 797 of Social and Legal Sciences, and 3239 of Engineering and Architecture. This is an asymmetric sample; however, considering the initial expectations, it was the best possible sample.

In the gender distribution, the male population was overrepresented, 3188 responses, (62\%), compared to the female 1923 responses, (38\%). This was due to the weight of the engineering and architecture branches in the total of the received inquiries. Figure 2 shows the gender ratio of the participants by area.

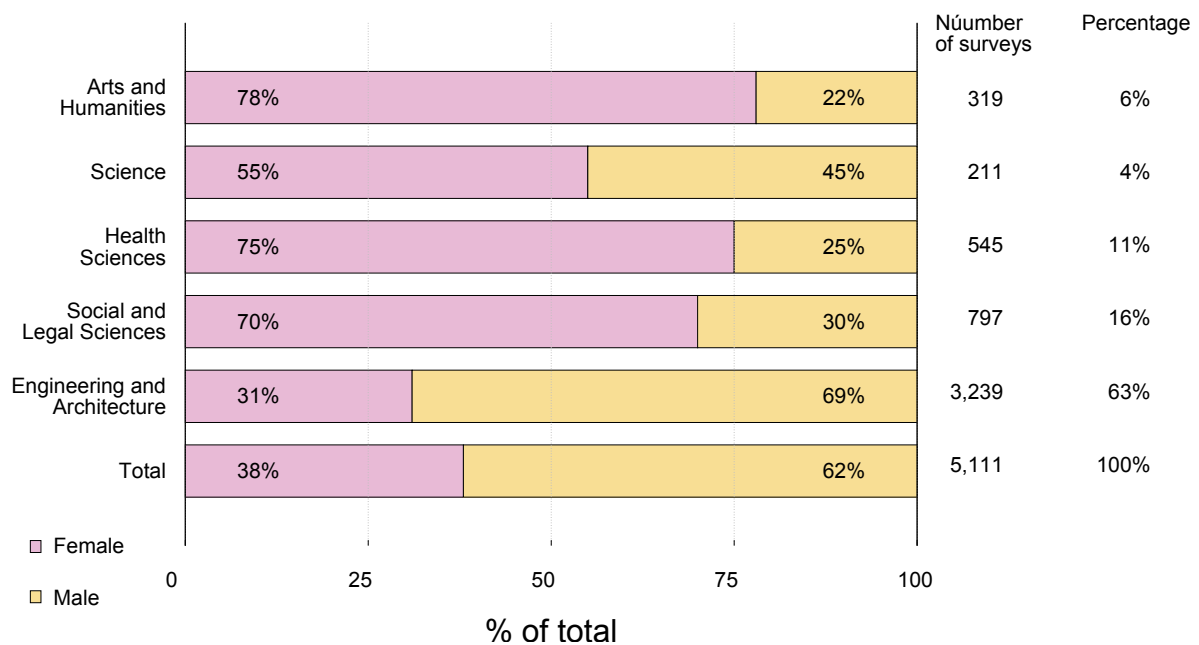

Figure 2. Gender ratio of the participants by area.

\subsection{Instrument}

Two versions of the form were prepared. An electronic web one, which was accessed via a link contained in the invitation sent by e-mail, and a paper version, with the objective that interested collaborators supply them to the students, and later forward the filled forms to us with their degree and university center identification. In both survey formats, the student anonymity was guaranteed.

The final sample was made up of $76 \%$ web surveys and $24 \%$ paper surveys.

The design of the survey was aimed at minimizing rejection by the survey respondents. We looked to:

- Minimize the vertical scrolling of the survey pages. Ensure that the questions in each section will be covered at a glance.

- Give information about the position of the question in the survey set.

- The respondent knew at any time the total number of unanswered questions.

- Minimize the number of questions that needed to use a keyboard.

The supply and demand for seats of each Center-Degree were obtained from the Register of Universities, Centers, and Degrees (RUCT) of the Spanish Ministry of Education and Science (MECyD). The system of identification and coding of context data was complex since there were unexpected problems, such as universities where the same degree was given in more than one center, usually on different campuses, so the degree was unique, but the center was not. In order to relate each survey to the supply data, it was required to assign an identifying code to each University-Center-Grade in the SUPE. To do this, we obtained, from the MECyD, the codes of the degrees, centers, universities, and 
their supply of seats. A unique code of supply was obtained by concatenating these three codes, to which the data of each survey were referenced.

The web surveys were personalized for each university, including in them the structure of all their centers grades. In order to compact the page as much as possible, a list of the centers integrated into their university was offered to the respondent. Once a center was selected, the grade degrees corresponding to the center were displayed. In this way, the grade's unique code was registered with the rest of the survey data.

In order to assess the web survey, we controlled, in detail, the whole process in one university, from the invitation to Lime-Survey information such as the IP used to connect or the time spent. The response rate was close to $20 \%$, and only $4 \%$ of the surveys were made from an internet connection inside the university. The average completion time of the surveys was between 2.5 and $3 \mathrm{~min}$, which was similar to the average time used to complete the surveys on paper. Respondents preferred to answer from their own computers (tablets, computers, or smartphones). After obtaining the results of the questionnaire and the required data of each student, the data were processed according to the statistical analysis as planned, using SPSS 21.0 and Amos 19.0.

\section{Results}

\subsection{Indicators for Adjusting the Model Parameters}

The data obtained by the described procedures were processed using SPSS v21.0 and Amos v19.0, obtaining the model parameters for the data set and the most relevant clusters, and also the indicators that allowed us to evaluate, in a standard way, the level at which the model fit the data.

Table 1 shows the general indicators of the adjustment of the structural model. The values show a reasonable adjustment in the five adjusted models. It was especially important to analyze the values of GFI (Goodness of Fit Index) , AGFI (Adjusted Goodness of Fit Index), BBNFI (Bentler Bonnet Normed Fit Index), BBNNFI (Bentler Bonnet Non-Normed Fit Index), and CFI (Comparative Fit Index). The closer these values come to the unit the better the adjustment is in the case of RMSE (Root Mean Square Error) values close to 0 . Therefore, the different indicators show the good fit of the model $\left(\chi^{2} / d f<5\right.$; GFI, ACFI, BBNFI, BBNNFI y CFI $\geq 0.90$; y RMSEA $\left.\leq 0.06\right)$, [38,39].

Table 1. Indices of goodness of fit.

\begin{tabular}{|c|c|c|c|c|c|}
\hline Indices & $\begin{array}{c}\text { Arts } \\
\mathrm{n}=319\end{array}$ & $\begin{array}{l}\text { Science } \\
\mathrm{n}=211\end{array}$ & $\begin{array}{l}\text { Health } \\
n=545\end{array}$ & $\begin{array}{c}\text { Social } \\
n=797\end{array}$ & $\begin{array}{c}\text { Engineering } \\
\mathrm{n}=3239\end{array}$ \\
\hline Goodness of Fit Index (GFI) & 0.941 & 0.977 & 0.953 & 0.944 & 0.974 \\
\hline $\begin{array}{l}\text { Adjusted Goodness } \\
\text { of Fit Index (AGFI) }\end{array}$ & 0.942 & 0.942 & 0.955 & 0.946 & 0.986 \\
\hline $\begin{array}{l}\text { Bentler Bonnet Normed } \\
\text { Fit Index (BBNFI) }\end{array}$ & 0.931 & 0.955 & 0.949 & 0.955 & 0.975 \\
\hline $\begin{array}{l}\text { Bentler Bonnet Non-Normed } \\
\text { Fit Index (BBNNFI) }\end{array}$ & 0.912 & 0.962 & 0.948 & 0.962 & 0.982 \\
\hline Comparative Fit Index (CFI) & 0.920 & 0.933 & 0.923 & 0.929 & 0.959 \\
\hline Coefficient of determination (R2) & 0.387 & 0.472 & 0.512 & 0.489 & 0.512 \\
\hline Root Mean Square Error (RMSE) & 0.007 & 0.007 & 0.006 & 0.007 & 0.003 \\
\hline $\begin{array}{c}\text { Standardized Root } \\
\text { Mean Square Error (SRMSE) }\end{array}$ & 0.003 & 0.003 & 0.002 & 0.003 & 0.002 \\
\hline$\chi^{2}$ with $\mathrm{df}=321$ & $\begin{array}{c}783.24 \\
(p<0.05)\end{array}$ & $\begin{array}{c}889.17 \\
(p<0.05)\end{array}$ & $\begin{array}{c}722.25 \\
(p<0.05)\end{array}$ & $\begin{array}{c}780.24 \\
(p<0.05)\end{array}$ & $\begin{array}{c}923.24 \\
(p<0.05)\end{array}$ \\
\hline Ratio $\chi^{2} / \mathrm{df}$ & 2.44 & 2.77 & 2.25 & 2.44 & 2.99 \\
\hline
\end{tabular}

The reliability study, as the internal consistency of each of the latent factors in each adjusted model, was estimated from the Cronbach alpha coefficient. The values are shown in Table 2. In all cases, the reliability was adequate since the Cronbach's alpha coefficient values were higher than 0.70 , even being excellent when this value was higher than 0.85 [40]. 
Table 2. Reliability values of the latent factors.

\begin{tabular}{cccccc}
\hline $\begin{array}{c}\text { Latent Factor } \\
\text { Reliability Values }\end{array}$ & $\begin{array}{c}\text { Arts } \\
\mathbf{n}=\mathbf{3 1 9}\end{array}$ & $\begin{array}{c}\text { Science } \\
\mathbf{n = 2 1 1}\end{array}$ & $\begin{array}{c}\text { Health } \\
\mathbf{n}=\mathbf{5 4 5}\end{array}$ & $\begin{array}{c}\text { Social } \\
\mathbf{n}=\mathbf{7 9 7}\end{array}$ & $\begin{array}{c}\text { Engineering } \\
\mathbf{n}=\mathbf{3 2 3 9}\end{array}$ \\
\hline Consideration of the university & $\alpha=0.723$ & $\alpha=0.779$ & $\alpha=0.823$ & $\alpha=0.813$ & $\alpha=0.813$ \\
Perceived Employability & $\alpha=0.732$ & $\alpha=0.767$ & $\alpha=0.799$ & $\alpha=0.822$ & $\alpha=0.822$ \\
Social Consideration & $\alpha=0.751$ & $\alpha=0.712$ & $\alpha=0.701$ & $\alpha=0.781$ & $\alpha=0.841$ \\
Vocational aspects & $\alpha=0.744$ & $\alpha=0.773$ & $\alpha=0.785$ & $\alpha=0.715$ & $\alpha=0.885$ \\
Surrounding environment & $\alpha=0.721$ & $\alpha=0.744$ & $\alpha=0.729$ & $\alpha=0.755$ & $\alpha=0.895$ \\
Geographic location & $\alpha=0.702$ & $\alpha=0.788$ & $\alpha=0.741$ & $\alpha=0.787$ & $\alpha=0.897$ \\
\hline
\end{tabular}

Consequently, the results were within the limits of the adjustment, and were most acceptable in all cases. This leads us to conclude that the model was valid, not only at the global level but also at the branch level.

The model presented in Figure 1 shows a part dedicated to the measurement structures for each of the latent variables that comprise it. The results in Table 1 indicate the overall adjustment of the model referring to each of the five areas studied. In addition to this analysis, we found it convenient to estimate the values of configurational invariance to assess whether the formulated factorial structure was kept constant across the five areas studied. The argument was simple in the sense that each area evaluated implied a minimal adaptation of the questionnaire used and, therefore, it was advisable to establish the invariance of the structure. The results shown in Table 3 clearly indicate the constancy of the factorial structure and the maintenance, therefore, of theoretically defined latent factors.

Table 3. Invariance stimation with five samples.

\begin{tabular}{ccccccccc}
\hline Model & $\chi^{2}$ & DF & Ratio & CFI & TLI & AIC & BIC & RSMR \\
\hline $\begin{array}{c}\text { Configurational } \\
\text { Invariance }\end{array}$ & 1123.12 & 467 & 2.404 & 0.993 & 0.9901 & -66234.12 & -66434.17 & $0.02(0.01-0.03)$ \\
\hline
\end{tabular}

\subsubsection{Estimation of the Structural Parameters}

Each parameter $\gamma_{2 j}$ indicates the effect on the final endogenous variable $Y_{2}$ of each exogenous latent variables $\xi_{1}, \xi_{2}$, and $\xi_{3}$.

According to the Equations (1) and (5), the values of the $\gamma_{i j}$ are a measure of the sensitivity of the endogenous variable $i$ to changes in the exogenous variable. Hence, its usefulness is not to describe a reality but its patterns of change.

For example, in Table 4B, the value of $\gamma_{23}$ for the branch of experimental sciences was 0.543 , and for the branch of Social Sciences was 0.714. This indicates that the demand for the studies of social sciences was more sensitive to the perception of the supply and demand ratio than the demand for studies of experimental sciences. 
Table 4. Estimation (and statistical significance) of each standardized structural parameter. (A) and (B) by area, (C) by engineering area, and (D) by industrial engineering degree.

\begin{tabular}{|c|c|c|c|c|c|c|c|c|c|}
\hline \multicolumn{2}{|c|}{$\begin{array}{l}\text { Beginning of the } \\
\text { effect according } \\
\text { to the model }\end{array}$} & \begin{tabular}{|c|} 
Previous \\
year's \\
enrollment
\end{tabular} & $\begin{array}{l}\text { Seats } \\
\text { supply } \\
\text { in the } \\
\text { previous } \\
\text { year }\end{array}$ & $\begin{array}{c}\text { Seats } \\
\text { supply } \\
\text { in the year } \\
\text { of } \\
\text { admission }\end{array}$ & \begin{tabular}{|c|} 
Social \\
Factors
\end{tabular} & $\begin{array}{l}\text { Indivi- } \\
\text { dual } \\
\text { Factors }\end{array}$ & $\begin{array}{c}\text { Perception } \\
\text { of supply } \\
\text { / demand } \\
\text { in the year } \\
\text { of } \\
\text { admission }\end{array}$ & $\begin{array}{c}\text { Correlation } \\
\text { between } \\
\text { Social and } \\
\text { Individual } \\
\text { Factors } \\
\end{array}$ & \multirow{2}{*}{$\begin{array}{l}\text { Correlation } \\
\text { between the } \\
\text { perceived } \\
\text { supply and } \\
\text { the demand } \\
\text { in the } \\
1^{\text {st }} \text { option in } \\
\text { the previous } \\
\text { year with } \\
\text { the } \\
\text { Individual } \\
\text { Factors }\end{array}$} \\
\hline \multicolumn{2}{|c|}{$\begin{array}{l}\text { End of the effect } \\
\text { according to the } \\
\text { model }\end{array}$} & \multicolumn{2}{|c|}{$\begin{array}{l}\text { Seats supply in the } \\
\text { year of admission }\end{array}$} & \multicolumn{4}{|c|}{$\begin{array}{c}1^{\text {st }} \text { demand choice/ in the year of } \\
\text { admission }\end{array}$} & & \\
\hline \multicolumn{10}{|c|}{ (A) FOR A LARGE SIZE GENERAL UNIVERSITY } \\
\hline \multicolumn{2}{|c|}{ Parameter (sample size) } & $\beta_{11}$ & $\beta_{12}$ & $\beta_{21}$ & $\gamma_{21}$ & $\gamma_{22}$ & $\gamma_{23}$ & $\varphi_{21}$ & $\varphi_{32}$ \\
\hline \multirow{2}{*}{ Areas } & $\begin{array}{c}\text { Social } \\
\text { Sci }(1289)\end{array}$ & $0.388^{* *}$ & $0.879 *$ & $0.775^{*}$ & $0.621 *$ & $0.704^{*}$ & $0.443^{*}$ & $0.377^{*}$ & $0.412 *$ \\
\hline & $\begin{array}{c}\text { Experimen } \\
\text {-tal Sciences } \\
(1778)\end{array}$ & $0.778^{*}$ & $0.804^{*}$ & $0.801 *$ & $0.771^{*}$ & $0.691 *$ & $0.803^{*}$ & $0.527^{*}$ & $0.871^{*}$ \\
\hline \multicolumn{10}{|c|}{ (B) FOR A SPECIALIZED UNIVERSITY OF AVERAGE SIZE } \\
\hline \multicolumn{2}{|c|}{ Parameter (sample size) } & $\beta_{11}$ & $\beta_{12}$ & $\beta_{21}$ & $\gamma_{21}$ & $\gamma_{22}$ & $\gamma_{23}$ & $\varphi_{21}$ & $\varphi_{32}$ \\
\hline \multirow{5}{*}{ Areas } & $\begin{array}{c}\text { Social } \\
\text { Science }(215)\end{array}$ & $0.321 *$ & $0.441 *$ & $0.328^{*}$ & $0.402 *$ & $0.621 *$ & $0.714^{*}$ & $0.443 *$ & $0.329^{*}$ \\
\hline & $\begin{array}{l}\text { Experimental } \\
\text { Sciences }(204)\end{array}$ & $0.221 * *$ & $0.277^{* *}$ & $0.216^{* *}$ & $0.344^{* *}$ & $0.651 * *$ & $0.543^{* *}$ & $0.612 * *$ & $0.881^{* *}$ \\
\hline & $\begin{array}{c}\text { Engineering } \\
(429)\end{array}$ & $0.602 * *$ & $0.776^{* *}$ & $0.229 *$ & $0.421^{* *}$ & $0.599 * *$ & $0.622 * *$ & $0.544^{* *}$ & $0.786^{*}$ \\
\hline & Arts (163) & $0.699^{* *}$ & $0.605^{*}$ & $0.311^{* *}$ & $\underset{* *}{0.502}$ & $0.502^{* *}$ & $0.612^{* *}$ & $0.501^{* *}$ & $0.699^{* *}$ \\
\hline & $\begin{array}{c}\text { Health } \\
\text { Science (184) }\end{array}$ & $0.601 *$ & $0.599 *$ & $0.433^{* *}$ & $0.592 *$ & $0.613 *$ & $0.677^{*}$ & $0.487^{*}$ & $0.745^{*}$ \\
\hline \multicolumn{10}{|c|}{ (C) FOR A SPECIALIZED UNIVERSITY OF AVERAGE SIZE } \\
\hline \multicolumn{2}{|c|}{ Parameter (sample size) } & $\beta_{11}$ & $\beta_{12}$ & $\beta_{21}$ & $\gamma_{21}$ & $\gamma_{22}$ & $\gamma_{23}$ & $\varphi_{21}$ & $\varphi_{32}$ \\
\hline \multirow{4}{*}{$\begin{array}{l}\text { Engi- } \\
\text { neering } \\
\text { areas }\end{array}$} & Agronomy(45) & $0.198^{*}$ & $0.218^{*}$ & $0.256^{*}$ & $0.399^{*}$ & $0.643^{*}$ & $0.501^{*}$ & $0.512^{*}$ & $0.621^{*}$ \\
\hline & $\begin{array}{c}\text { Construction } \\
(82)\end{array}$ & $0.335^{*}$ & $0.321 *$ & $0.299 *$ & $0.441^{*}$ & $0.678^{*}$ & $0.592 *$ & $0.571^{*}$ & $0.699^{*}$ \\
\hline & ICT (102) & $0.644^{*}$ & $0.612^{*}$ & $0.618^{*}$ & $0.649 *$ & $0.612^{*}$ & $0.676^{*}$ & $0.623^{*}$ & $0.679^{*}$ \\
\hline & Industrial(80) & $0.216^{*}$ & $0.299^{*}$ & $0.261^{*}$ & $0.381^{*}$ & $0.551^{*}$ & $0.423^{*}$ & $0.493^{*}$ & $0.612^{*}$ \\
\hline \multicolumn{10}{|c|}{ (D) FOR A SPECIALIZED UNIVERSITY OF AVERAGE SIZE } \\
\hline \multicolumn{2}{|c|}{ Parameter (sample size) } & $\beta_{11}$ & $\beta_{12}$ & $\beta_{21}$ & $\gamma_{21}$ & $\gamma_{22}$ & $\gamma_{23}$ & $\varphi_{21}$ & $\varphi_{32}$ \\
\hline \multirow{5}{*}{$\begin{array}{l}\text { Degrees } \\
\text { of Engi- } \\
\text { neering }\end{array}$} & $\begin{array}{c}\text { Industrial } \\
\text { Electronics(123) }\end{array}$ & $0.541 *$ & $0.676^{*}$ & $0.229 *$ & $0.221 *$ & $0.399 *$ & $0.555^{*}$ & $0.321 *$ & $0.551 *$ \\
\hline & $\begin{array}{c}\text { Industrial } \\
\text { Chemistry(63) }\end{array}$ & $0.304^{*}$ & $0.177^{*}$ & $0.216^{*}$ & $0.244^{*}$ & $0.451 *$ & $0.487^{*}$ & $0.344^{*}$ & $0.661 *$ \\
\hline & Mechanics(66) & $0.299^{*}$ & $0.341^{*}$ & $0.328^{*}$ & $0.302^{*}$ & $0.329^{*}$ & $0.501^{*}$ & $0.329^{*}$ & $0.628^{*}$ \\
\hline & Electric (206) & $0.201^{*}$ & $0.318^{*}$ & $0.256^{*}$ & $0.299^{*}$ & $0.243^{*}$ & $0.488^{*}$ & $0.461^{*}$ & $0.559^{*}$ \\
\hline & $\begin{array}{l}\text { Industrial } \\
\text { Design(82) }\end{array}$ & $0.289 *$ & $0.421^{*}$ & $0.299 *$ & $0.341 *$ & $0.578 *$ & $0.522 *$ & $0.422 *$ & $0.712 *$ \\
\hline
\end{tabular}

* Statistical significance: $p<0.05$; ${ }^{* *}$ Statistical significance: $p<0.01$.

The interest of knowing these coefficients of $\gamma$ is that they allow, from the $\gamma_{i j}$ of a given group, to establish which factors it is more effective to act on in order to improve the demand, while the rest of the constant factors are kept constant.

For example, if we look for the most effective actions to improve the demand for experimental science degrees, we should keep in mind that:

- The $\gamma_{23}$ is the lowest among the branches (0.543), and thus the sensitivity to changes in the perception of supply and demand is the lowest. 
- The $\gamma_{21}$ is the lowest among the branches; thus, the sensitivity to enhance social factors has an expected effect of only 0.344 standard deviations in the demand for each standard deviation that can improve the perception of these factors.

- The $\gamma_{22}$ is the highest among the branches, with a value of 0.651 . The efforts to improve the perception of individual factors among students demanding a degree will have a maximum impact on this group of degrees.

\subsection{Detail of the Adjustment Indicators for Universities, Branches, and Grades}

Our objective was to analyze the access to the SUPE and the behavior of the model, determining the differences among universities, areas, and degrees.

To ease this task, the structural parameters were collected in four blocks in Table 4. In the block (A) we collected the values obtained for a generalist, traditional and large university, with 65,000 students, and corresponding to two areas, social and experimental sciences. In block (B) we collected the values obtained for a specialized university, a polytechnic, created in the last century, medium-sized, 36,000 students, and corresponding to the areas of engineering, arts, social, experimental, and health sciences. In block (C) for this last university, we have disaggregated the estimates of the variables of the area of engineering and architecture in the branches of Agronomy, Construction, Industrial, and ICT (Information and Communication Technologies). Finally, in block (D), within the industrial branch, we obtained the estimates for each of the engineering degrees that are taught in this university: Electronics, Chemistry, Mechanics, Electrical, and Industrial Design.

In order to verify the goodness of the indicators even through the reduction of the sample size, we calculated the fit goodness of indicators corresponding to the last group of degrees. See Table 5.

Table 5. Indices of goodness of fit for Table 4D.

\begin{tabular}{cccccc}
\hline Indices & $\begin{array}{c}\text { Industrial } \\
\text { Electronics }\end{array}$ & $\begin{array}{c}\text { Industrial } \\
\text { Chemistry }\end{array}$ & $\begin{array}{c}\text { Mechanics } \\
\text { Electric }\end{array}$ & $\begin{array}{c}\text { Industrial } \\
\text { Design }\end{array}$ \\
\hline Goodness of Fit Index (GFI) & 0.921 & 0.943 & 0.899 & 0.900 & 0.877 \\
Adjusted Goodness of Fit Index (AGFI) & 0.925 & 0.944 & 0.887 & 0.901 & 0.878 \\
Bentler Bonnet Normed Fit Index (BBNFI) & 0.901 & 0.901 & 0.885 & 0.900 & 0.871 \\
Bentler Bonnet Non-Normed Fit Index (BBNNFI) & 0.902 & 0.903 & 0.884 & 0.902 & 0.873 \\
Comparative Fit Index (CFI) & 0.899 & 0.899 & 0.891 & 0.899 & 0.878 \\
Coefficient of determination (R2) & 0.301 & 0.294 & 0.287 & 0.312 & 0.302 \\
Root Mean Square Error (RMSE) & 0.010 & 0.009 & 0.011 & 0.010 & 0.010 \\
Standardized Root Mean Square Error (SRMSE) & 0.003 & 0.003 & 0.004 & 0.004 & 0.005 \\
$\chi^{2}$ with df = 240 & 554.11 & 734.12 & 612.88 & 594.23 & 643.28 \\
Ratio $\chi^{2} / \mathrm{df}$ & $p=0.05$ & $p=0.06$ & $p=0.09$ & $p=0.078$ & $p=0.069$ \\
\hline
\end{tabular}

As expected, the fit goodness of the indicators was slightly worse than those for the whole sample.

In any case, according to the criteria set in the previous section, the indicators corresponded to the category of "acceptable" in the fields of Electronic, Chemical, and Electrical Engineering. The Mechanical and Industrial Design Engineering were in the threshold of acceptability.

\section{Discussion}

The differences in responses among students of different degrees allowed us to draw some conclusions regarding different aspects of their visions and interests. Table $4 \mathrm{~A}, \mathrm{~B}$ shows the estimates of the variables by university and area. Table $4 \mathrm{~B}$ corresponds to the medium size specialized university, and Table $4 \mathrm{~A}$ corresponds to the large size general university. We can see that the system discriminates for the same areas in different universities. This can be due to different causes, likely the difference between the number of seats offered. However, in any case, the model for each university provided some values that allowed us to analyze them individually. 
In block (C), for the second university, we disaggregated the estimates of the variables of the area of engineering and architecture in the branches of Agronomy, Construction, Industrial, and ICT. The results confirmed that the model allowed discriminating each one of them. In block (D), we obtained the estimates for each of the engineering degrees that are taught in this university in the industrial branch: Electronics, Chemistry, Mechanics, Electrical, and Industrial Design. As in the previous case, the results confirmed that the model allowed discriminating each of them.

The aspirations of the students, which were reflected in the survey, were very different in many aspects among the different degrees. The differences do not seem to be large in terms of the assessment of the individual factors by the students of the different branches. However, they are affected differently by different aspects of the factor. Thus, the vocational aspects had a maximum valuation in Arts and Humanities, while it was minimal in Engineering and Architecture. The students of Engineering and Architecture were more sensitive than those of Arts and Humanities regarding the influence of the near and familiar surroundings.

As for the geographical location, the proximity of the university to the family home was not, in general, a factor that was considered relevant, especially for those who wished to study Health Sciences degrees. The social consideration of the degree was especially valued by those who entered Engineering and Architecture studies, and little valued by those of Arts and Humanities. The consideration of the chosen university reached high levels in all the branches, especially in Experimental Sciences, Engineering, and Architecture.

The analysis of the results allowed us to obtain information about the SUPE that otherwise would not have been possible to obtain. We found that the fit between the model and the data obtained was excellent at the global level and at least acceptable in all branches of knowledge. From the general model and the available data, we broke down the application of the model for universities and branches of knowledge, and verified that the model allowed the discrimination of the behaviors of students, in the case of both universities and branches.

We deepened the study, comparing, within a branch of knowledge, the results of the same titles in different universities, and we verified that there were factors that provided similar results, but also made noticeable differences. Consequently, we state that the proposed model can serve as an aid in decision making, in particular, in the design of recruitment actions, depending on the interests or needs of each title, branch, or university.

The following aspects remain to be studied:

- The realization of a new institutional survey that would allow us to obtain a not asymmetric and adjusted sample to the number of students of the SUPE. Clearly, this is far from our possibilities and could only be approached with institutional leadership at the highest level that allows for the technical and human capacity to produce this new survey.

- To develop a simulator from the model that allows university managers to adjust the values of the parameters, to be able to analyze the results, and thus, have a vision of the problem adapted to their needs.

- To periodically conduct the study. This would allow us to have tools to analyze the behavior of the parameters over time, as there are many factors that influence the student's choice, and the temporal evolution could make any of the conditions vary.

In summary, we presented a model that fit the problem, gave an overview of the behavior of the students at the time of deciding the degree and university in which they are going to study, and that can help both in the decision making of university leaders and to understand the behaviors of the SUPE. 


\section{A Case Study}

In 2000, the explosion of the digital bubble and the fall of the .com companies caused an economic movement that had consequences on the universities: the demand for ICT degrees plummeted during the period of 2001-2006, and did not start to recover until a few years later. A similar phenomenon occurred in Spain in 2007 with the construction sector crisis affecting the degrees of this branch, and as of today still exhibits a stagnant demand at historically low values.

Could the structural model we have presented be useful to predict the effects on the demand of events that affect Social Factors, Individuals, or the Perception of supply and demand? Could it help to establish corrective effects that would prevent further damage to the system?

In order to verify this, we considered the following case: as in the immediate environment of the specialized University to which we referred to in Table $4 \mathrm{~B}$ there is an automobile factory of a known American brand, we proposed the following situation:

What effect would the closure of this factory have on related engineering degrees?

If the automobile manufacturing plant closes, this would affect the circle of companies that carry out their activity around it, indicating a strong economic and social impact. As the industrial activity related to the plant employs a significant proportion of graduates in Mechanical Engineering, its disappearance would decrease the perceived utility of the degree, and the assessment of its set of Social Factors would be reduced.

Having a sufficient number of surveys and reaching different scopes, we can estimate the parameters of the model, and we would be able to:

1. Propose a value for the set of social factors resulting from the closing event, based on the values for the degree in geographical areas in which the current conditions are similar to those that would result from the event.

2. Calculate the model parameters that allow us to estimate the effects of the closing event on the demand $\left(\gamma_{21}, \gamma_{22}, \gamma_{23}, \varphi_{21}, \varphi_{32}\right)$.

The reduction of $\xi_{1}$, expressed as typical deviations $S D \xi_{1}$, is converted through the coefficient $\gamma_{21}$ into the reduction of demand $Y$ of the following year, also expressed in standard deviations (SDY).

However, as the model expresses, the effects on demand would not end there. The indirect effects on demand should also be added through the individual factors, as well as those produced through them on the perception of supply and demand. See Table 6.

Table 6. The effects on demand.

\begin{tabular}{clccc}
\hline Year & Effect on Demand $S D Y_{n}$ & Factor & Effect SD & Demand Effect \\
\hline $\mathrm{n}$ & Social Factors & $S D \xi_{1} \cdot \gamma_{21}$ & -0.55 & 49.5 \\
$\mathrm{n}$ & Through Individual Factors & $S D \xi_{1} \cdot \varphi_{21} \cdot \gamma_{22}$ & -0.23 & 20.3 \\
$\mathrm{n}$ & Through Individual Factors through & $S D \xi_{1} \cdot \varphi_{21} \cdot \varphi_{32} \cdot \gamma_{23}$ & -0.17 & 15.5 \\
& Supply and Demand Perception & & \\
\hline
\end{tabular}

Although we considered that the reduction in the social factors valuation $S D \xi_{1}$ occurs in a single year, there will be reductions (SDY) in the demand in successive years due to the influence of the reduction of the demand itself on the perception of supply and demand. The reduction of demand in year $n\left(S D Y_{n}\right)$, following the event, will lead to a reduction in the cut-off mark, as an indicator of the supply and demand perception, which will lead to a reduction in demand for the year $n+1,\left(S D Y_{n+1}\right)$. See Table 7. 
Table 7. Evolution of the effect on demand.

\begin{tabular}{llcccc}
\hline Year & Effect on Demand & Factor & $\begin{array}{c}\text { Previous } \\
\text { Year's } \\
\text { Demand }\end{array}$ & $\begin{array}{c}\text { Cut-off } \\
\text { Mark }\end{array}$ & $\begin{array}{c}\text { Demand } \\
\text { Effect }\end{array}$ \\
\hline $\mathrm{n}+1$ & Average grade of students entering universities & $S D Y_{n} \cdot \gamma_{23}$ & 319 & 9.90 & -46.2 \\
$\mathrm{n}+2$ & Average grade of students entering universities & $S D Y_{n+1} \cdot \gamma_{23}$ & 227 & 8.86 & -7.3 \\
$\mathrm{n}+3$ & Average grade of students entering universities & $S D Y_{n+2} \cdot \gamma_{23}$ & 180 & 8.42 & -5.1 \\
\hline
\end{tabular}

The magnitude of the effect depends on the conversion of the decrement into the number of claims to decrement in the cut-off mark, which is a function of the distribution of the cut-off mark in the degree. The most favorable case is that the most frequent access notes are concentrated around the cut-off mark since a reduction of demand will result in a slight decrease in the cut-off mark. See Figure 3.

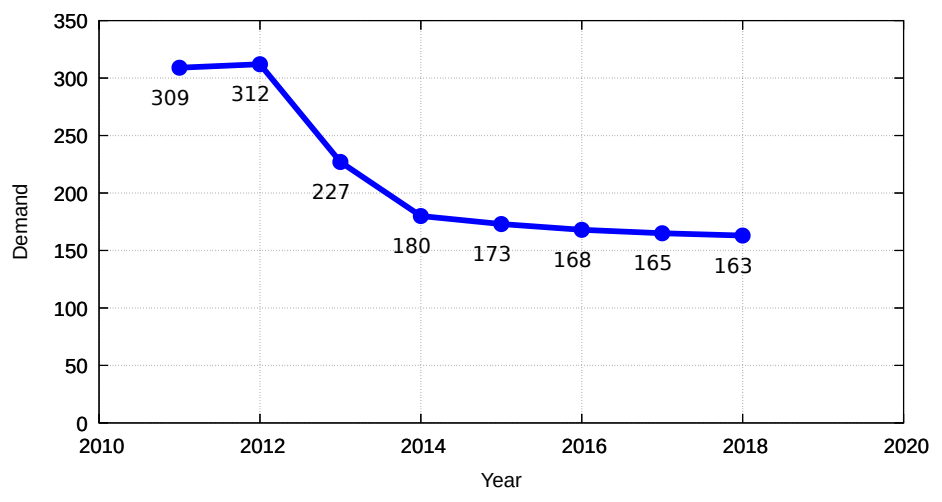

Figure 3. Estimated demand in the first option.

Another question to ask is: could we act to reduce the effect?

Since the only variable on which we can act is the supply of places, we will do so. In this case, if we reduce the supply of places by 10 units, the behavior of the model tells us that within a period of three years we would recover the trend. See Figure 4.

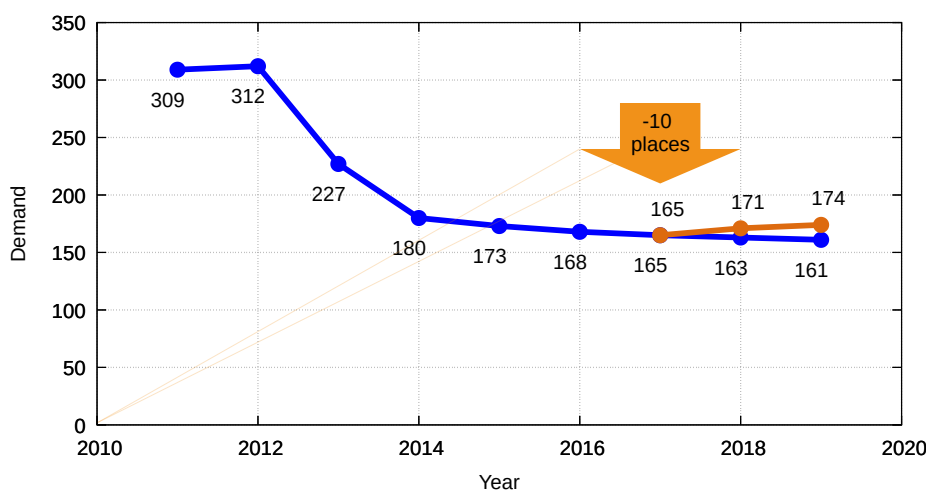

Figure 4. Estimated and corrected demand in the first option.

To do these simulations, we used the simulator proposed by [41], and it is available in http:/ / marte.itaca.upv.es:8888/.

Author Contributions: Conceptualization, A.H., P.P.S. and J.G.i.O.; Data curation, P.P.S. and R.C.; Formal analysis, A.H., J.G.i.O. and M.P.; Funding acquisition, A.H.; Investigation, A.H., P.P.S. and J.M.M.; Methodology, A.H., P.P.S. and J.G.i.O.; Project administration, A.H. and J.M.M.; Resources, A.H.; Supervision, A.H. and J.G.i.O.; Validation, A.H., J.G.i.O., M.P. and R.C.; Writing-original draft, A.H. and P.P.S.; Writing-review \& editing, A.H., J.G.i.O., M.P., R.C. and J.M.M. All authors have read and agreed to the published version of the manuscript. 
Funding: This work was funded by the Project "Complex Networks" from the Instituto Universitario de Matematica Multidisciplinar (IUMM) of the Universitat Politècnica de València (UPV) [grant number (266500194) 20170251-Complex-Networks-UPV].

Conflicts of Interest: The authors declare no conflict of interest. The funders had no role in the design of the study; in the collection, analyses, or interpretation of data; in the writing of the manuscript, or in the decision to publish the results.

\section{Abbreviations}

The following abbreviations are used in this manuscript:

$\begin{array}{ll}\text { AGFI } & \text { Adjusted Goodness of Fit Index } \\ \text { BBNFI } & \text { Bentler Bonnet Normed Fit Index } \\ \text { BBNNFI } & \text { Bentler Bonnet Non-Normed Fit Index } \\ \text { CFI } & \text { Comparative Fit Index } \\ \text { DF } & \text { Degrees of Freedom } \\ \text { EBAU } & \text { Spanish Baccalaureate Assessment for University Access } \\ \text { GFI } & \text { Goodness of Fit Index } \\ \text { ICT } & \text { Information and Communication Technologies } \\ \text { MECyD } & \text { Spanish Ministry of Education and Science } \\ \text { NCEE } & \text { Chinese National College Entrance Examination } \\ \text { PAU } & \text { Spanish entrance examination } \\ \text { R2 } & \text { Coefficient of determination } \\ \text { RMSE } & \text { Root Mean Square Error } \\ \text { RUCT } & \text { Spanish Register of Universities, Centers and Degrees } \\ \text { SRMSE } & \text { Standardized Root Mean Square Error } \\ \text { SUPE } & \text { Spanish Public University System }\end{array}$

\section{References}

1. Naylor, R.A.; Smith, J. Determinants of Educational Success in Higher Education; Edward Elgar Publishing Limited: Northampton, MA, USA, 2004; pp. 415-461.

2. Belvis, E.; Moreno, M.V.; Ferrer, F. Explanatory Factors for the Academic Success and Failure in Spanish Universities during the Process towards European Convergence. Revista Española de Educación Comparada 2009, 1, 61-92.

3. George, S.; Long, P. Penetrating the Fog: Analytics in Learning and Education. EDUCAUSE Rev. 2011, 46, 30.

4. Cristobal, R.; Ventura, S. Educational data mining: A survey from 1995 to 2005. Expert Syst. Appl. 2007, 33, 135-146.

5. Behrouz, M.B.; Kashy, D.A.; Kortemeyer, G.; Punch, W.F. Predicting student performance: An application of data mining methods with an educational web-based system. In Proceedings of the 33rd Annual Frontiers in Education, Westminster, CO, USA, 5-8 November 2020; pp. 13-18.

6. Guerra, G.; Rueda, E.M. Estudio Longitudinal de los Jóvenes en el Tránsito de la Enseñanza Secundaria a la Universidad: Orientación, Expectativas, Toma de Decisiones y Acogida de los Nuevos Estudiantes en la Universidad; Dirección General de Universidades, Estudios y Análisis: Valladolid, Spain, 2005; Available online: https: / / fracasoacademico.files.wordpress.com/2019/06/estudio-transito-a-universidad-_completo.pdf (accessed on 3 June 2020).

7. Capilla, R. Análisis Estratégico de los Estudios TIC en la Universidad Politécnica de Valencia. Ph.D. Thesis, Universidad Politécnica de Valencia, Valencia, Spain, 2009.

8. Perna, L.W.; Titus, M.A. Understanding differences in the choice of college attended: The role of state public policies. Rev. High. Educ. 2004, 27, 501-525. [CrossRef]

9. Price, I.F.; Matzdorf, F.; Smith, L.; Agahi, H. The impact of facilities on student choice of university. Facilities 2003, 21, 212-222. [CrossRef]

10. Gratacós, G.; López-Jurado, M. Validation of the Spanish Version of the Factors Influencing Teaching (FIT)-Choice scale. Revista de Educación 2016, 1, 83-105. 
11. Felix, M. University and course choice: Implications for positioning, recruitment and marketing. Int. J. Educ. Manag. 2006, 20, 466-479.

12. Oner, Y.H. How does the image of engineering affect student recruitment and retention? A perspective from the USA. Glob. J. Eng. Educ. 2002, 6, 17-23.

13. Parry, J.; Mathers, J.; Stevens, A.; Parsons, A.; Lilford, R.; Spurgeon, P.; Thomas, H. Admissions processes for five year medical courses at English schools: Review. Br. Med. J. 2006, 332, 1005-1009. [CrossRef]

14. Becker, R.; Kolster, R. Intl Student Recruitment: Policies and Developments in Selected Countries. Available online: https:/ / research.utwente.nl/en/publications/international-student-recruitment-policiesand-developments-in-se (accessed on 3 June 2020).

15. Shane, D.; Macfadyen, L.; Lockyer, L.; Mazzochi-Jones, D. Using social network metrics to assess the effectiveness of broad based admission practices. Australas. J. Educ. Technol. 2011, 27, 16-27.

16. P-Nuffic. The Chinese Education System Described and Compared with the Dutch System. Available online: https:/ / www.nuffic.nl/en/publications/education-system-china/ (accessed on 3 June 2020).

17. P-Nuffic. Information about the Education System of South Korea and the Evaluation of Degrees Obtained in South Korea. Available online: https:/ / www.nuffic.nl/documents/491/education-system-south-korea.pdf (accessed on 3 June 2020).

18. P-Nuffic. The American Education System Described and Compared with the Dutch System. Available online: https:/ / www.nuffic.nl/en/publications/education-system-united-states/ (accessed on 3 June 2020).

19. Murphy, P.E.; McGarrity, R.A. Marketing universities: a survey of student recruitment activities. Coll. Univ. 1978, 53, 249-261.

20. Ford, D.Y. The underrepresentation of minority students in gifted education: Problems and promises in recruitment and retention. J. Spec. Educ. 2008, 31, 4-14. [CrossRef]

21. Leppel, K.; Williams, M.L.; Waldauer, C. The Impact of Parental Occupation and Socioeconomic Status on Choice of College Major. J. Fam. Econ. Issues 2001, 22, 373-394. [CrossRef]

22. Turner, C.S.V.; Thompson, J.R. Socializing Women Doctoral Students: Minority and Majority Experiences. Rev. High. Educ. 1993, 16, 355-70. [CrossRef]

23. Huffman, A.H.; Whetten, J.; Huffman, W.H. Using technology in higher education: The influence of gender roles on technology self-efficacy. Comput. Hum. Behav. 2013, 29, 1779-1786. [CrossRef]

24. Misran, N.; Nurhanum-Syed-Sahuri, S.; Arsad, N.; Hussain, H.; Diyana-Wan-Zaki, W.M.; Aziz, N.A. The Influence of Socio-Economic Status among Matriculation Students in Selecting University and Undergraduate Program. Procedia Soc. Behav. Sci. 2012, 56, 134-140. [CrossRef]

25. León Serrano, G. Nuevos enfoques para la gestión estratégica de I+D e innovación en las universidades. Revista de Educación Ministerio de Educación Centro de Publicaciones 2011, 1, 83-108.

26. Tinto, V. Research and practice of student retention: What next? J. Coll. Stud. Retent.: Res. Theory Pract. Baywood 2006, 8, 1-19. [CrossRef]

27. Ministerio de Educación, Cultura y Deporte. Datos y Cifras del Sistema Universitario Español. Available online: https: / / www.educacionyfp.gob.es/dam/jcr:aa35d8fe-ffbd-4142-8cca-9a093cc1d9de/datos-y-cifrasdel-sue-curso-2014-2015.pdf (accessed on 3 June 2020).

28. P-Nuffic. The Spanish Education System Described and Compared with the Dutch System. Available online: https:/ / www.nuffic.nl/en/publications/education-system-spain/ (accessed on 3 June 2020).

29. Universidad de Las Palmas de Gran Canaria. Plan de Captación de Estudiantes. Available online: http:/ / www.ff.ulpgc.es/system/files/plan_captacion_estudiantes._2017-2018.pdf (accessed on 3 June 2020).

30. Universidad Politècnica de València. Orientación: Actividades para Secundaria. Available online: http: / / www.upv.es/contenidos/ORIENTA/info/794644normalc.html (accessed on 3 June 2020).

31. Universitat Politècnica de Valencia. Campus Praktikum UPV. Available online: http://www.upv.es/ contenidos/PRAKTIKUM/ (accessed on 3 June 2020).

32. Universidad Politècnica de València. Programa Valentina. 2007. Available online: http://www.valentinas. upv.es/proyecto_valentina_upv.html (accessed on 3 June 2020).

33. Real Academia de Ingeniería. Mujer e Ingeniería. Available online: http://www.raing.es/es/actividades/ presentaci-n-del-proyecto-mujer-e-ingenier (accessed on 3 June 2020).

34. Universidad de Murcia. Servicios de Información y Orientación Universitarios. Available online: http: //www.um.es/web/siou/inicio (accessed on 3 June 2020). 
35. Hervás, A.; Guàrdia, J.; Peró, M.; Capilla, R.; Soriano-Jiménez, P. A Structural Equation Model for Analysis of Factors Associated with the Choice of Engineering Degrees in a Technical University. Abstr. Appl. Anal. 2013, 2013, 368529. [CrossRef]

36. Peró, M.; Soriano-Jiménez, P.; Capilla, R.; Guàrdia, J.; Hervás, A. Questionnaire for the assessment of factors related to university degree choice in Spanish public system: A psychometric study. Comput. Hum. Behav. 2014, 47, 128-138. [CrossRef]

37. Guàrdia, J.; Peró, M.; Hervás, A.; Capilla, R.; Soriano-Jiménez, P.; Porras, M. Factors related with the university degree selection in Spanish public university system. An structural equation model analysis. Qual. Quant. 2015, 49, 541-557.

38. Hu, L.; Bentler, P.M. Cutoff criteria for fit indexes in covariance structure analysis: Conventional criteria versus new alternatives. Struct. Equ. Model. Multidiscip. J. 1999, 6, 1-55. [CrossRef]

39. Schumacker, R.; Lomax, R. A Beginner's Guide to Structural Equation Modeling; Lawrence Erlbaum Associates, Inc.: Mahwah, NJ, USA, 1996.

40. Muñiz, J. Utilización de los tests. In Análisis de los Items; Muñiz, J., Fidalgo, A., García-Cueto, E., Martínez, R., Moreno, R.E., Eds.; Editorial La Muralla: Madrid, Spain, 2005; pp. 133-172.

41. Hervás, A.; Soriano Jiménez, P.P.; Iranzo, J.; Lemus Zúñiga, L.G.; Ivorra Martínez, E. A web-based application tool for university career choosing factors analysis. In Proceedings of the Mathematical Modelling in Engineering \& Human Behaviour, Valencia, Spain, 19 July 2017.

(C) 2020 by the authors. Licensee MDPI, Basel, Switzerland. This article is an open access article distributed under the terms and conditions of the Creative Commons Attribution (CC BY) license (http://creativecommons.org/licenses/by/4.0/). 